\title{
THE CONTROL OF ANOPHELINE MOSQUITOS BY THE SPRAYING OF DELTAMETHRIN ON RAFFIA CURTAINS USED IN MINERS' HUTS IN AREAS ENDEMIC FOR MALARIA
}

\author{
Regina FIGUEIREDO(1), Wanderli P. TADEI(1) \& Bedsy Dutary THATCHER(1)
}

\begin{abstract}
SUMMARY
The residual potential of an aqueous solution of Deltamethrin (FW $25 \mathrm{mg}$ i.a. $/ \mathrm{m}^{2}$ ) was evaluated on raffia curtains. These are sheets of synthetic material used in the construction of huts to house miners. Experiments were conducted during 420 days and the curtains were always rolled up in the daytime and unrolled in late afternoon. Data analyzed by logarithmic regression indicated that raffia treated with Deltamethrin had higher mortality indices than that covered with DDT. The residual capacity of Deltamethrin on raffia was high. The mortality percentage was above $85 \%$ after 360 days and dropped to about $50 \%$ at 420 days. The effect of DDT was reduced after 180 days and reached zero by the end of the experiment. Based on the results of these experiments, it is recommended that Deltamethrin be used to spray raffia curtains in mining regions and other areas that are endemic for malaria.
\end{abstract}

KEYWORDS: Malaria; Deltamethrin; Raffia; Anophelines; Mosquito

\section{INTRODUCTION}

The number of cases of malaria in Amazonia continues high in some localities and even increased during 1996. DDT is the insecticide used in the struggle against the vectors of this disease in the area. However, the organochlorates create problems in the environment because they are relatively stable and highly toxic. Also, they are more liposolvent than hydrosolvent and therefore can accumulate in terrestrial or aquatic ecosystems within humans and other animals ${ }^{3,6,12}$. This situation and the increase in the number of cases of malaria in tropical countries ${ }^{20,21}$, justifies the search for and the utilization of alternative insecticides and additional control strategies that could compliment residual spraying. Deltamethrin, a synthetic pyrethroid, is being used extensively in public health campaigns s.8, $11,15^{\text {. }}$

Some of these strategies, including the use of impregnated mosquito nets, have given good results in BurkinaFaso and in the $\mathrm{Congo}^{2}$. In Africa ${ }^{9,10}$, however, malaria more frequently affects children under 10 years of age, whereas in Amazonia adults of more than 15 years of age are more often infected. Anopheles gambiae is most active between 21:00 and 23:00 hours while A. darlingi usually shows increased biting activity between 19:00 and 22:00 hours ${ }^{16}$. The latter species may feed all night, however, during periods of high density. During the rainy season, when the density of this species is lowest, it's biting activity peaks from 19:00 to 21:00 hours which favors the use of impregnated bed nets. In regions of the Gambia ${ }^{17}$, where the mosquitos have a high level of sporozoites but a low incidence of biting, bed nets proved efficient. However, the people found the nets somewhat uncomfortable and there was a tendency to use them less which brought on an increase in the mortality among children.

In Equador, Peru and Colombia ${ }^{5}$, programs to promote the use of mosquito nets impregnated with pyrethroids in areas endemic for malaria, demonstrated that the important factors for the success of the program were: the susceptibility of the insects to the pyrethroids; the use of curtain material with a high rate of absorption; a high degree of coverage by the mosquito nets; a good cooperation of the populace, including not washing the nets very often. These studies showed that impregnated nets were a better control of anopheline mosquitos than the traditional DDT spraying. Some of the advantages were: the populace participated actively in impregnating the nets so that fewer technical personnel were needed; the method was cheaper than DDT spraying and pyrethroids are more biodegradable.

Malaria and other diseases have a direct financial effect on the patient and his family. In addition to the cost of diagnosis, treatment, trips to the hospital and a special diet for the patient, the adults stop working and the children often stay home from school. A study done in Gujarat, In-

(1) Instituto Nacional de Pesquisas da Amazônia CPCS, Caixa Postal 478, 69011-970 Manaus, AM, Brasil. 
FIGUEIREDO, R.; TADEI, W.P. \& THATCHER, B.D. - The control of anopheline mosquitos by the spraying of deltamethrin on raffia curtains used in miners'huts in areas endemic of malaria. Rev. Inst. Med. trop. S. Paulo, 40 (2): 107-111, 1998.

$\mathrm{dia}^{4}$, estimated that the cost of lost working days due to malaria was about $40 \%$, while similar studies in a rural area of Sri Lanka indicated economic losses of $15.56 \%$ for malaria and $47.46 \%$ for other diseases. During the season of high malarial transmission, $5.6 \%$ of the working days were lost and the children lost $10 \%$ of their school days. Cost and motivation have been limiting factors in the use of treated bed nets in the control of malaria and these should be taken into account before introducing the method in an endemic area ${ }^{4}$.

The residual activity of Deltamethrin under natural conditions in Amazonia is one of the aspects of chemical control that needs to be determined. SALGADO CAVALCANTE ${ }^{13}$ evaluated the residual action of aqueous Deltamethrin, compared to that of DDT, on raffia curtains and those made of natural jute, on huts in the vicinity of placer mines. These experiments were conducted during 8 months in the Brazilian State of Amapa. The results showed: 1. the repellent effect of both insecticides, 2. the more prolonged residual activity of Deltamethrin and 3. raffia as a material that favors the action of insecticides. However, the duration of the effectiveness of Deltamethrin on that substrate was not determined. In continuing this work, it was our objective to discover how long Deltamethrin remains effective on raffia surfaces using curtains and huts similar to those used by miners. The curtains were rolled up by day and down by night as is the custom of the miners. Cases of malaria among miners contribute considerable to the high levels of infection noted in recent years.

\section{MATERIALS AND METHODS}

The study was carried out in an isolated part of the campus at INPA (Brazilian National Institute for Amazonian Research). Huts with raffias curtains, similar to those used by miners, were constructed and were then sprayed with insecticides. The concentration of DDT (PM) $75 \%$ used was 2 grams of active ingredient per square meter. Deltamethrin was used as an aqueous suspension K-Othrine Flow - SC50 (Deltamethrin $5 \%$ ) at a concentration of $25 \mathrm{mg}$ i.a. $/ \mathrm{m}^{2}$ and a dilution of $125 \mathrm{ml} / 10$ liters of water. Both insecticides were applied at the beginning of the experiment. The curtains were rolled up each morning and unrolled each evening which is the way they are used by miners.

The residual activity of the insecticides was evaluated by means of biological tests as recommended by $\mathrm{WHO}^{19}$ which consists of placing plastic cones, each containing 15 female mosquitos, on the treated surfaces and reading the results after 30 minutes and after 24 hours. Monthly tests were made using unfed female anophelines that had been captured in a cattle corral located at Km 204 on the Manaus/ Boa Vista highway (BR-174).

Statistical analysis: the basis of the entire analysis is logistic regression which is similar to classic regression analysis but with two important differences:

1) The variable in this case is a percentage of mortality, transformed into its $\operatorname{logit}(\operatorname{logit}=\log (\%$ dead $) /(\%$ alive $)$ ). When the regression coefficient of a variable that influences the mortality rate is positive, it indicates that the variable increases mortality and the opposite is true for a negative coefficient.

2) When a variable that influences mortality is of a qualitative type (such as a kind of insecticide or face $\mathrm{A}$ or $\mathrm{B}$ etc.) the coefficient indicates the increase (or decrease) of the logit with a particular state of that variable. For example, the insecticide could be DDT or Deltamethrin and a coefficient of 0.5 would indicate that the logit of the mortality increased by 0.5 in respect to DDT and decreased by 0.5 when the insecticide was Deltamethrin.

\section{RESULTS AND DISCUSSION}

Deltamethrin maintained high mortality percentages during 420 days (Table 1). A striking reduction occurred only after 360 days when there was a drop from $87.42 \%$ to $64.33 \%$. In regard to DDT, an abrupt drop was seen 180 days after treatment, from $72.37 \%$ to 42.38 . Both experimental groups were protected against the daily solar radiation.

The coefficients estimated by means of logarithmic regression (Table 2) for the variable Months after application were negative indicating a reduction in the activity of both insecticides. The positive coefficient for Deltamethrin $(+0.991)$ and the negative for DDT (-0.991) suggests that the first showed all its potential in 30 minutes while the latter had greater activity after 24 hours. For the interaction Raffia $x$ Insecticide, the coefficient was negative for raffia $x$ DDT (-0.639) and positive for deltamethrin indicating a low mortality for DDT and a superior performance by Deltamethrin. The mortality index for DDT dropped from 1 to 0 during 360 days while Deltamethrin performed much better and had a mortality index that dropped from 10 to 1 over the course of 360 days (Fig. 1).

DDT showed values slightly above 50 after 24 hours of exposure (Table 3 and Fig. 2) in the readings of 30 and 60 days while the value for Deltamethrin was 150 . On the third reading, taken at 90 days, DDT fell to 10 and continued to drop reaching values below $1(0.18)$ at 360 days. Deltamethrin maintained the same standard up to 270 days with reductions at 180, 210 and 300 days with indices between 14 and 7.

By means of the angle of the rectilinear regression curve, it can be seen that DDT had a reduction in indices of about 
FIGUEIREDO, R.; TADEI, W.P. \& THATCHER, B.D. - The control of anopheline mosquitos by the spraying of deltamethrin on raffia curtains used in miners'huts in areas endemic of malaria. Rev. Inst. Med. trop. S. Paulo, 40 (2): 107-111, 1998.

TABLE 1

Anopheline mortalities obtained on raffia curtains sprayed with either DDT or deltamethrin in Manaus between April. 1994 and May. 1995.

\begin{tabular}{cccccc}
\hline $\begin{array}{c}\text { Days after } \\
\text { treatment }\end{array}$ & FW & $\begin{array}{c}\text { Number of anophelines } \\
\text { DDT }\end{array}$ & C & FW & \multicolumn{2}{c}{ Mortality numbers } \\
DDT
\end{tabular}

()$=$ Percentage

()$^{*}=$ Percentage corrected by Abbvott's formula

$\mathrm{FW}=$ aqueous Deltamethrin $(5 \%)$

$\mathrm{C}=$ control

TABLE 2

Coefficients predicted by regression analysis of the variables that were significant for the mortality of Anopheles nuneztovari after 30 minutes.

\begin{tabular}{lccc}
\hline Variable & Coefficient & $\begin{array}{c}\text { Standard } \\
\text { Deviation }\end{array}$ & $\begin{array}{c}\text { Similarity } \\
\text { Index }\end{array}$ \\
\hline $\begin{array}{l}\text { Months after application } \\
\text { Surface }\end{array}$ & -0.297 & 0.0069 & $1310.2(1)$ \\
$\quad$ Raffia & 0.952 & & $297.4(3)$ \\
Insecticide & & & $1733.1(1)$ \\
DDT & -0.991 & 0.0292 & $1625.6(3)$ \\
Deltamethrin & 0.991 & & \\
Surface x Insecticide & -0.639 & & \\
Raffia x DDT & & & \\
\hline
\end{tabular}

TABLE 3

Mortality indices for Anopheles nuneztovari predicted by logistic regression based on biological tests on raffia curtains. 24 hours after exposure.

\begin{tabular}{|c|c|c|c|c|c|c|c|c|c|c|c|c|}
\hline \multirow[b]{2}{*}{ Insecticide } & \multicolumn{12}{|c|}{ Days after application } \\
\hline & 30 & 60 & 90 & 120 & 150 & 180 & 210 & 240 & 270 & 300 & 330 & 360 \\
\hline FW & 150 & 150 & 150 & 131 & 150 & 24.20 & 70 & 150 & 150 & 14 & 6.45 & 6.94 \\
\hline DDT & 31.20 & 59 & 7.64 & 4.78 & 3.40 & 3.08 & 0.75 & 0.86 & 0.24 & 0.73 & 0.35 & 0.35 \\
\hline
\end{tabular}

$\mathrm{FW}=$ aqueous deltamethrin at $5 \%$ 
FIGUEIREDO, R.; TADEI, W.P. \& THATCHER, B.D. - The control of anopheline mosquitos by the spraying of deltamethrin on raffia curtains used in miners'huts in ateas endemic of malaria. Rev. Inst. Med. trop. S. Paulo, 40 (2): 107-111, 1998.

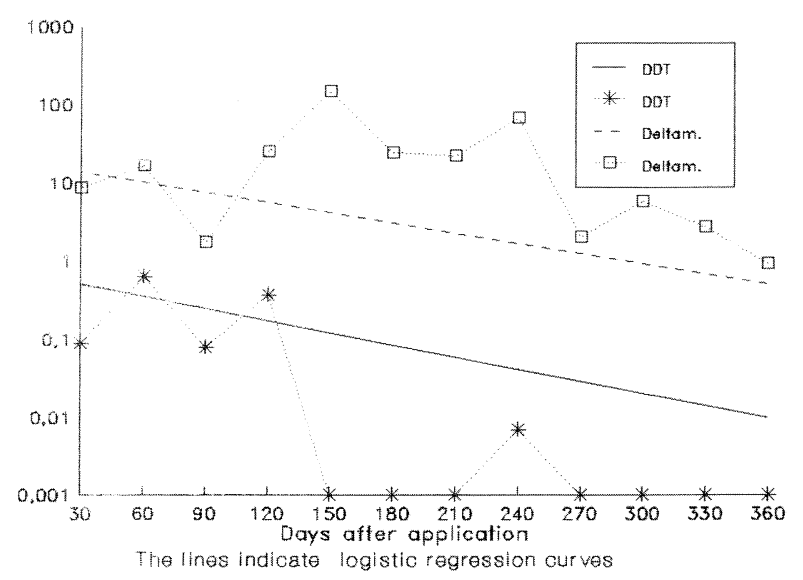

FIG. 1 - Mortality indices on raffia after 30 minutes

1.8 to 0.18 while the curve for Deltamethrin showed values that fell from about 63 to 10 . The tests indicate a more prolonged residual effect for Deltamethrin as compared to DDT The loss of activity of Deltamethrin was gradual while that of DDT was more abrupt.

Deltamethrin is a high potency insecticide that differs from the others in being composed of only one active isomere which is effective at extremely low concentrations. It is rapidly netabolized by warmblooded vertebrates or degraded by microbial action and therefore represents a minimal risk for humans, domestic animals and for the environment ${ }^{14}$.

XAVIER \& LIMA $^{18}$ demonstrated that curtains made of jute fibers and impregnated with Deltamethrin were effective in the control of malaria in mining areas of Amapa. In the present study, in which we measured the persistence time of Deltamethrin on raffia curtains, the results exceeded our expectations. This insecticide maintained high levels of mortality during the 420 days of the being protected from solar radiation.

In China , during the period 1985 to 1987 , the residual effect of Deltamethrin impregnated curtains on exposed mosquitos was tested. The curtains killed the mosquitos at $8.5,10.5$ and 37.7 minutes after 1,6 and 12 months respectively. On the Isle of Hainan, using curtains impregnated with Deltamethrin at a dosage of $25 \mathrm{mg}$ i.a. $\mathrm{m}^{2}$ a $100 \%$ mortality was obtained, after 11 months of domestic use, in 16 minutes of contact. They also verified that an increase in the LT50 to 19.5 minutes only occurred after the curtains were washed.

These observations could contribute to a better control of malaria in the Amazon if the following recommendations were applied. Deltamethrin should be used instead of DDT because of its more prolonged residual effect. Raffia curtains should be used in mining areas and these should be

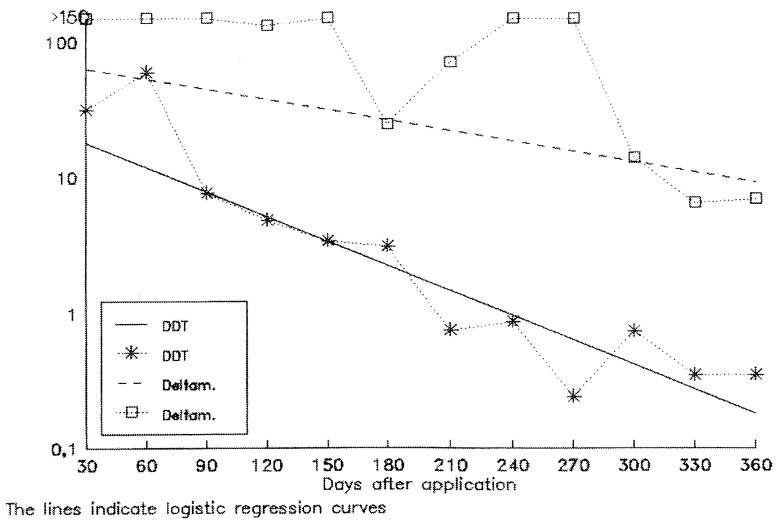

FIG. 2 - Mortality indices on raffia after 24 hours

impregnated with Deltamethrin annually. Impregnated raffia curtains should be used on windows and doors of houses in other endemic areas. Also, the residents of these houses should be taught to let the curtains down at night and roll them up during the day. In this way, the pyrethroid is protected from the destructive effect of sunlight.

\section{RESUMO}

\section{O controle de anofelinos pela borrifação de deltametrina nas cortinas de ráfia utilizadas nas barracas dos garimpeiros nas áreas endêmicas de malária}

O poder residual da deltametrina FW (25 mg i.a./m2) foi avaliado em cortinas de ráfia tecido sintético, utilizadas na construção das barracas nos garimpos. Foram realizadas provas biológicas de parede, durante 420 dias, sendo as cortinas laterais das barracas enroladas durante o dia e desenroladas no final da tarde. Os dados da regressão logística evidenciaram que a ráfia impregnada com a deltametrina apresenta taxas de mortalidade superiores à tratada com DDT. O poder residual da ráfia/deltametrina mostrou efeito elevado, atingindo índices de mortalidade acima de $85 \%$ aos 360 dias, diminuindo em quase $50 \%$ aos 420 dias. O efeito do DDT foi reduzido aos 180 dias, chegando a zero de mortalidade ao final do experimento. Mediante o resultado do tratamento dado à ráfia, recomenda-se seu emprego em barracas nos garimpos e áreas endêmicas de malária.

\section{ACKNOWLEDGMENTS}

This research was supported by the Brazilian Council for Scientific and Technological Development (CNPq) and Commercial and Industrial Chemical Products S.A. 
FIGUEIREDO, R.; TADEI, W.P. \& THATCHER, B.D. - The control of anopheline mosquitos by the spraying of deltamethrin on raffia curtains used in miners'huts in areas endemic of malaria. Rev. Inst. Med. trop. S. Paulo, 40 (2): 107-111, 1998.

\section{REFERENCES}

1. BITSINDOU,G.G.P.- Impact des traitements insecticides (DELTAMETHRINE) sur la transmission du paludisme et sa morbidité dans un village des environs de Brazzaville. Rép. du Congo, 1982. (Thése de doctorat de 3e cycle - Univ. Paris Sud Orsay, France).

2. CARNEVALE,P.- Insecticide impregnation restores the efficiency of torn bed nets and reduces man-mosquito contacts. In: LATIN AMERICAN CONGRESS OF TROPICAL MEDICINE, 3., México, 1990. p.11.

3. DAMATO, M.- Avaliação da toxicidade de praguicidas organoclorados (Lindano e Endrin) para Phalloceros caudimaculatus (Teleostei, Poeciliidae). São Paulo, 1988. (Dissertação de Mestrado - Instituto de Biociências da Universidade de São Paulo).

4. KONRADSEN, F.; VAN DER HOEK, W.; AMERASINGHE, P.H \& AMERASINGHE, F.P. - Measuring the economic cost of malaria to households in Sri Lanka. Amer. J. trop. Med. Hyg., 56: 656660, 1997.

5. KROEGER, A.; MANCHENO, M.; ALARCON, J. \& PESSE, K. Insecticide impregnated bed nets for malaria control: varying experiences from Ecuador, Colombia, and Peru concerning acceptability and effectiveness. Amer. J. trop. Med. Hyg., 53: 313-323, 1995.

6. LHOSTE, J. \& L' HOTELLIER,M. - Acciones secundarias del deltametrín sobre el medio ambiente. In: ROUSSEL-UCLAF, ed. Deltametrín. Avignon, 1983. p.325-358.

7. LIZUZI; ZHANG MANCHENG; SHEN MEIWU; LI MINGXING \& ZHANG LONGFU - Field trial of deltamethrin impregnated bed nets for the control of Anopheles dirus transmitted malaria in Hainan island, China. Geneva, World Health Organization, 1988. (WHOIVBC 187.939).

8. LIZUZI; XU JINJIANG; LI BANGQUAN; ZHU TAIHUA; LI MINGXING- Mosquito nets impregnated with deltamethrin against malaria vectors in China. Geneva, World Health Organization, 1989. (WHOIVBC 187.939 ).

9. LYIMO, E. O.; MSUYA, F. H. M.; RWEGOSHORA, R. T. et al - Trial of pyrethroid impregnated bednets in an area of Tanzania holoendemic for malaria. Part 3. Effects on the prevalence of malaria parasitemia and fever. Acta trop. (Basel.), 49: 157-163, 1991.

10. MSUYA, F.H.M. \& CURTIS, C.F.- Trial of pyrethroid impregnated bednets in an area of Tanzania holoendemic for malaria. Part.4. Effects on incidence of malaria infection. Acta trop. (Basel), 49: 165- 171, 1991.

11. PAN AMERICAN HEALTH ORGANIZATION \& WORLD HEALTH ORGANIZATION-Informal consultation on the use of impregnated bednets and other materials for vector-borne disease control. Washington, PAHO/WHO, 1989. p. 5.
12. RABELLO, M. N. - Estudo citogenético de indivíduos profissionalmente expostos ao DDT. São Paulo, 1974. (Tese de Doutoramento- Instituto de Biociências da Universidade de São Paulo).

13. SALGADO CAVALCANTE, E. T. - Avaliação da deltametrina para o controle da malária em áreas de garimpo. Manaus, 1993. (Dissertação de Mestrado - Instituto Nacional de Pesquisas da Amazônia)

14. SAUME,F. \& MALDONADO,J. - La deltametrina una alternativa fiable y polivalente en el control del vector de malaria, dengue y Chagas. In: SIMPOSIUM LATINO AMERICANO SOBRE BIOLOGIA Y CONTROL DE VECTORES DE ENFERMEDADES EN HUMANOS, 2., Estado Nueva Esparta, Venezuela, 1993. Resumos. p. 1-5.

15. SAUME, F.; HERNANDEZ, A.; VERA, J.; SALCEDO, A.; LEDEZMA, M. -Comportamiento del K-Othrine en el control de Anopheles aquasalis en el Estado Sucre (1987).In: SIMPOSIUM LATINO AMERICANO SOBRE BIOLOGIA Y CONTROL DE VECTORES DE ENFERMEDADES EN HUMANOS, 2., Estado Nueva Esparta, Venezuela, 1993. Resumos. p.6.

16. TADEI, W.P.; SANTOS, J.M.M.; SCARPASSA, V.M. \& RODRIGUES, I.B. - Incidência, distribuição e aspectos ecológicos de espécies de Anopheles (Diptera: Culicidae), em regiões naturais e sob impacto ambiental da Amazônia Brasileira. In: FERREIRA, E.J.G.; SANTOS, G.M.; LEÃO, E.L.M. \& OLIVEIRA, L.A., ed. Bases científicas para estratégias de preservação e desenvolvimento da Amazônia. Manaus, Instituto Nacional de Pesquisas da Amazônia, 1993. v. 2, p. 167-196.

17. THE GAMBIA'S NATIONAL IMPREGNATED BEDNET PROGRAMME (NIBP)- Positive bednet results from the Gambia. In: ANNUAL MEETING OF UNDP/WORLD BANK/WHO SPECIAL PROGRAMME FOR RESEARCH AND TRAINING IN TROPICAL DISEASES (TDR). Gambia, 1994.

18. XAVIER,P.A. \& LIMA,J.E.N.- O uso de cortinas impregnadas com deltametrina no controle da malária em garimpos no território federal do Amapá. Rev. bras. Malar., 38: 137-139, 1986.

19. WORLD HEALTH ORGANIZATION- Manual on practical entomology in malaria. Part II. Methods and techniques. Geneva, WHO, 1975.

20. WORLD HEALTH ORGANIZATION - Global malaria control strategy. Bull. Pan Amer. Hlth. Org., 27: 280-283, 1993.

21. WORLD HEALTH ORGANIZATION- A rapid dipstick antigen capture assay for the diagnosis of falciparum malaria. Geneva, World Health Organization, 1995. (WHO/MAL/95.1072).

Recebido para publicação em 30/10/1997

Aceito para publicação em 11/02/1998 